Vol. 1, n² | 1997

Varia

\title{
Civil Society, State Law and Village Norm : Semantic Conflict in Nineteenth-Century Rural Germany
}

Regina Schulte

\section{(2) OpenEdition \\ Journals}

Electronic version

URL: https://journals.openedition.org/chs/1012

DOI: $10.4000 /$ chs. 1012

ISSN: 1663-4837

Publisher

Librairie Droz

\section{Printed version}

Date of publication: 1 June 1997

Number of pages: $75-89$

ISSN: $1422-0857$

\section{Electronic reference}

Regina Schulte, "Civil Society, State Law and Village Norm : Semantic Conflict in Nineteenth-Century Rural Germany", Crime, Histoire \& Sociétés / Crime, History \& Societies [Online], Vol. 1, n² | 1997, Online since 03 April 2009, connection on 25 March 2022. URL: http://journals.openedition.org/chs/1012 : DOI: https://doi.org/10.4000/chs.1012 


\section{Civil Society, State Law and Village Norm: \\ Semantic Conflict \\ in Nineteenth-Century Rural Germany'}

Regina Schulte

Tn order to learn something about bourgeois law in the second half of the nine-

teenth century, I checked out books and, reading them, found a codified text and commentaries to help me to understand it. This was my point of entry into the history of law, which belongs to a culture of writing and the binding force of the written word. I learned about the legal system, its institutions, and its guardians, who are called to interpret and enforce the law and to punish its infringement. Finally, I assumed that this body of texts is about the social norms which permeated nineteenth-century civil society, the most important of which, for me, are those regulating the family and property, life and death.

Why set up peasant norms as a separate category? Aren't they included in writing, which is universal? Aren't peasants, in this case those of Upper Bavaria, citizens? No written text exists which could allow me to compare peasant law with positive law: how, then, can I learn anything about peasant norms, beyond what we already know about the regulation of inheritance, the rigid practices and their regional customary variations which governed the passing down of peasant property?

In order to better understand the norms and unwritten laws of peasant life, I sought out the courts as places where I could meet peasants in those moments where they had violated norms and stood accused of crimes ${ }^{2}$. I proceeded here from the assumption that a culture's hidden norms, which have not left any explicit written record, become visible when they are violated, when the unspoken assumptions of the material and social order are exploded for a moment, and the peasant leaves the village to be questioned before a court of law ${ }^{3}$. It is precisely this moment, when countryfolk confronted a world of writing, of reports, a world which produced and provided the sources, which I attempt, as far as possible, to read as "peasant texts ". Confronted with questions relevant to the judicial process, the villagers begin to speak, as defendants and as witnesses.

Bundles of dusty, dry and crumbling papers tied up with ribbons, up to two hundred pages of illegible handwriting for each of hundreds of infanticide, arson and poaching cases constituted the materials in which I tried to glimpse the inner world

1 A slightly version of the present article has been given and printed as The Luigi Einaudi Chair Lecture (Cornell University, October 1992).

2 On the opposition between elite and popular cultures, (which I do not wish to reproduce here, addressing instead their points of intersection), whose overlappings are part of the historicity of each culture, see Chartier (1982).

3 Thompson (1977). On this unspoken level of reality see also Le Goff (1974). 
of the Upper Bavarian peasantry ${ }^{4}$. I was not interested in yet another description and analysis of their criminal deeds. Rather, I used infanticide, arson and poaching as a probe into a society in which - if we are to believe the archives - they had become everyday offenses. What more did I want to know? The verdicts, the final stage in the process which lay bundled before me in the files, were clear enough, after all. On the surface level of judicial reality, I had before me infanticides, arsonists and poachers. The Penal Code defined and provided a clear description of their crimes, and they had been sentenced accordingly. Their individual cases were closed. Only in comparing their lives and statements did I begin to glimpse a common cultural context and suspect that what I had before me was a way into the deep structures of the peasant world of Upper Bavaria, a world which would prove very foreign indeed. I had to proceed backwards from the verdict to the scene of the crime, to read the documents against the grain, not trusting in words alone but deciphering a language of dialect, regional and still permanently in flux, of action expressed in gesture and symbol.

Police reports and witnesses' accounts became the signposts to this "barbaric» village $^{5}$, where women, or so the bills of indictment suggested, killed their illegitimate newborn babies without any «particular» motive ${ }^{6}$, where men burned entire farms to the ground for apparently irrational, even trivial reasons and where, for the sheer joy of breaking the law, old and young men alike shot game on the royal hunting grounds and the preserves of aristocrats and well-heeled Munich burghers ${ }^{7}$, long after the old repressive feudal game law had been abolished.

These crimes had been brought to trial, and yet there seemed to exist a deep chasm between the arsonist and the infanticide as they were defined by the Reich Penal Code and criminal psychiatry - and as they had taken shape in my own mind before I knew them - and the figures I encountered in the Upper Bavarian records, figures who refused to fit the clichés of my own prejudice, as I would like to call it.

According to Franz von Liszt's Lehrbuch des Deutschen Strafrechts, infanticide is « the deliberate killing, whether premeditated or not, of an illegitimate child by its mother during or immediately after birth" (StGB $\$ 217$ ). The term thus includes both the murder and the manslaughter of a child... The object of the killing is the child, not the embryo... And it is the child either during ... or immediately after birth... The penalty for infanticide was milder than that for murder because of the strength of the motivations impelling the unmarried mother to kill and the diminished responsibility produced by the act of giving birth... The mother herself must be the perpetrator: not only the unmarried mother, but also the married woman bearing

4. The documents in question were the files of criminal cases heard before the assizes of Munich Provincial Courts (Landgericht) I and II and the Traunstein Provincial Court, in the second half of the 19th century, and records of the lower courts (Amtsgericht) of various districts in Upper Bavaria. Staatsarchiv Munich, Staatsanwaltschaftsakten (StAM, St Anw), Amtsgerichtsakten (StAM, AG), Akten der Landratsämter (StAM, LRA), Antiquar-Registratur München II (StAM, AR). For further analysis and sources, see Schulte (1989, in English, 1994).

5 The term «barbaric village» was coined by Theodor W. Adorno, but is also in the background of more recent village studies.

- In all, 15 cases were thus characterized, either by the defendant or the court.

7 In 1848, the government of Upper Bavaria thus interpreted village poaching in the context of the revolutionary events. 
an illegitimate child... The punishment is not less than three years hard labor or, under mitigating circumstances, not less than two years imprisonment ${ }^{8}$.

The infanticide of the Reich's Penal Code assumed her specific form in the eighteenth century, in the penal-reform debates of the Enlightenment and the literature of the Sturm und Drang Period in the 1770 s and $1780 \mathrm{~s}^{\circ}$. The woman's motivations for killing her baby were loss of sexual honor and the existential crisis in which she found herself. Her condition at the moment of birth exhibits traits of psychosis ${ }^{10}$. The literary figure of the child murderess - in the works of Goethe, Schiller, Wagner and later Hauptmann - is a simple, virtuous middle-class girl who, abandoned by her aristocratic seducer and rejected by a stern father and cruel society, bears and kills her child in desperation and madness.

In the interpretation of infanticide as a product of fornication, an immoral sexual act between unmarried people, the newly confident bourgeoisie, attacking aristocratic immorality, propagated its own sexual norms, which measured women's worth by their chastity before marriage, virginity and sexual honor. In his argument against the death penalty for infanticide, Immanuel Kant speaks of «sexual honor» as «true» honor, which representes women's duty. This high value placed upon sexual honor throws a particular light on infanticide and the illegitimate child:

As legislation cannot remove the stigma of an illegitimate birth ... it appears that in these cases human beings find themselves in a natural state and killing (homicidium), which in this case must not be murder (homicidium dolosum), although punishable in both cases, cannot be punished by death by the highest authorities. The child who enters the world out of wedlock is born outside the law (i.e. marriage), and thus beyond its protection. It has stolen into the commonweal (like contraband wares), and so the latter can ignore its existence (since it should not have come to exist in this way), and thus also its destruction, and no ordinance can alleviate the mother's shame, when the illegitimate birth is discovered...11

I encountered neither Wagner's Evchen nor Goethe's Gretchen nor Hauptmann's Rose Bernd among the sixty Bavarian women who were accused of infanticide between 1872 and 1910 and whose cases were filed in the Munich archives. None of these farm servants would have made a suitable character in a German drama, im Bürgerlichen Trauerspiel. Neither the literary nor the legal figure of the infanticidal mother corresponds to these women's tales. The child murderer of the drama, of the law-reform debates of the Enlightment and of the Reich Penal Code is a figure of civil bourgeois society itself. She is the counter-image of the ideal bourgeois daughter, sister and mother. But in the evidence of Criminal Statistics and Archival records, there were hardly any infanticidal bourgeois or middle-class mothers to be found. Nearly all of the infantical women, like those in Bavaria, came from the countryside and peasant society. They had by no means lost their sexual honor, since, among the rural lower classes to which they belonged, illegitimate children were part of everyday life.

8 Liszt (1903, p. 312f.). See also Meyer (1888, p. 522-526).

- See esp. the comprehensive newer study by Ulbricht (1990, part II, p. 217-258); Wächtershäuser (1973); Rameckers (1927); Weber (1974); Wittrock (1978).

10 Ulbricht (1990, p. 254).

11 Immanuel Kant, Metaphysik der Sitten, Rechtslehre, Part II, E « Vom Straf-und Begnadigungsrecht", Werke, Vol. 8, pp. 452-459, quoted in Wächtershäuser (1973, p. 31). 
In $1859,25.51 \%$ of children in Upper Bavaria were born out of wedlock. In 1901 the percentage was 18.9, and rural areas accounted for a large proportion of illegimate births ${ }^{12}$. Underlying this phenomenon was a family structure diverging markedly from that of the middle classes. Children were conceived out of wedlock, at a time when their parents were employed on different farms, for farmers did not take married people into service. Farm servants often did not marry until they were well into their thirties. Children were raised by grandparents or foster families. By the time the couple had formed its own household, its sons and daughters were often farm servants themselves, who might send home new grandchildren in a few years. Many of the Upper Bavarian infanticidal women already had children and had by no means slipped innocently into a situation of seduction and pregnancy. Another child would have meant hardship for many of them, but not an extreme life crisis. They needed fear neither unemployment nor banishment from family and community. Illegitimate children were no disgrace. The childrens' fathers were farmhands, day laborers, young artisans, journeymen and the like. More importantly, they came from the same strata of village society as the child murderesses. There was rarely a farmer among them. Finally, not one of the sixty infanticides I studied killed her child in a fit of insanity. Thus, from the standpoint of the Reich Penal Code, there were no extenuating circumstances which might apply to farm servants. And what Bavarian infanticide might have pleaded extenuating circumstances, since the vast majority of women brought to trial, some thirty a year, were farm servants?

What were the infanticide records talking about? I changed my perspective and concentrated on the network of police interrogations in the village and witnesses' statements before the police magistrates. I had before me servant girls, farmers' wives, farmers, farmhands, neighbors and villagers, and with them perceptions embedded in the run of days, months and cycles of the rural year. The texts spoke of farm labor and women's place in it. They told of love affairs among the servants and the sharpsightedness of farmers when a servant girl left the farm and was missing during the most labor-intensive time of the year because of pregancy and childbirth. They spoke of the overwhelming dominance of the peasant economy, of the need to avoid any disruption to the seasonal routine. This becomes particularly clear in the statements of child murderesses and other women about strategies for concealing pregnancy. Women worked harder than bevore to dispel any suspicions. A servant girl might leave the stall where she had been milking, or a guestroom she had just cleaned, in the evening, bear a child during the night, and return to work in the morning as if nothing had happened ${ }^{13}$. Or a farmgirl might let the farmhands go on ahead for a moment, give birth at the edge of a field, leave the baby there and reappear at work twenty minutes later ${ }^{14}$. Childbirth and work appear to flow into each other in an unbroken rhythm.

This pattern of everyday life, work, childbirth and work emerges most vividly in a farm servant's account of how the congestion of her blood was suddenly relieved in the stable privy, something came out, and the birth of the child, later found in the

12 See Lee (1977, p. 410); Lindner (1900, p. 70 ff.); Schweyer (1896, p. 38); Matz (1980, p. 247); Mitterauer $(1979,1983)$.

13 See, for example, StAM, St Anw 179.

14 StAM, St Anw 693. 
cesspit, appeared as a mere excretion ${ }^{15}$. How do we know that only infanticides gave birth in this way, and not other servants or even the occasional farmer's wife? When a farmer's wife bore a child, it was in a special place, within a ritual framework. Most infanticidal women, on the other hand, brought their children into the world alone and unaided, a result of the concealment of the pregnancy and birth. The records show that many of them were nevertheless embedded in female networks which consisted mainly of other servant girls, but which also, it appears, might include the farmer's wife, a neighbor or a midwife. Repeated accounts of guesses and questions about a maidservant's condition leave the impression that these women had recognized the physical signs of pregnancy. Speaking to constables or judges, however, they were willing at most to express suspicions. Many claimed to know nothing, to have seen and heard nothing, even if they shared a room with the accused. As long as suspicions about a maidservant's pregnancy stayed among the women, the infanticide might be detected only by accident. This fact points to the division of responsibilities in this peasant village society, in which women are the self-appointed guardians of knowledge about pregnancy and birth. In Tittmoning, a village near the Bavarian Alps, a constable abandoned his investigation of the mother of an infant found dead after the servant's mistress and a midwife assured him that no birth had taken place ${ }^{16}$. This servant had a good reputation and was a good worker. And at first they, the farmer's wife and the midwife, were still the competent authorities. Only a district physician brought in from outside and endowed with an official legal claim was able to break this circle.

How did it happen that peasant society, and first and foremost the women, shielded these infanticidal women, so that presumably many never reached the courts? Didn't the peasants, or rather the rural lower classes, love their children, those objects of middle-class parental solicitude and affection since the eighteenth-century? The records show that the accused women cared tenderly for their living children ${ }^{17}$. Perhaps it is their attitudes towards children's deaths which needs examining. Upper Bavarian peasants spoke of «Himmelnlassen », «leaving to Heaven » for the «widespread practice of ... postnatal family planning ${ }^{18}$ through more or less conscious child neglect. «Himmeln" gave parents at once the comforting and tender notion that the dead newborns would enter heaven as innocent angels and be spared this earthly vale of tears ${ }^{19}$.

Infanticides were often discovered by accident, not revealed by anyone. Among the cases I studied, however, many were reported to the village constable and via him to the magistrate ${ }^{20}$. The village itself now followed the Penal Code, from experience knowing which questions and answers were expected. In these cases a village instance, as I would like to call it, was formed when knowledge about a woman's pregnancy left the circle of women. This knowledge entered the village public

Is Account of Anna H. in StAM, StAnw 185. See also the cases in StAM, St Anw 89, 194, 700, 736, $858,940,984,1358,1446,1482$.

16 StAM, ST Anw 682.

17 See, for example, StAM, St Anw 194, 1177.

18 See also Hörger (1978, p. 779). On infant mortality, see Lee (1977, p. 417, p. 422). Between 1879 and 1888, for example, $33.5 \%$ of all children in Bavaria were either stillbom or died before their first birthday.

19 See Leoprechting (1975, p. 213, 216).

20 For example StAM, St Anw 179, 185, 682, 693. 
through rumor and talk at festivities or in taverns, and most particularly when the villagers' gaze fell upon the maidservant's swollen belly before the church $^{21}$. Suddenly the woman's body was seen as carrying a child, while in other cases her explanation of a mere tumor or a congestion of the blood would have been accepted by the women of the village.

It was the identity of the father that the villagers sought when they turned their eyes to the pregnant unmarried maidservant. It was the disgrace of a love affair with the «wrong» man - a married man, or the son of a farmer who deserved another kind of woman in the village hierarchy (a farmer's daughter), or a stranger - with whom, according to the village's notions, she had conceived an unsuitable bastard, who would now - having no father - strain the poor funds of the village. It was this outrage which caused the talk and made the villagers, both men and women, look at her so shamelessly. According to the strict village moral code, their eyes reflected the woman's own shamelessness. She had already lost her reputation before she killed her child, she was a loose woman and as such threatened the hierarchical and supposedly calculable economy of the peasant village's generative resources. Some of these women were unreliable workers who had quit their jobs during harvest time. Some of them had been accused of theft before, of having no respect for property - thus resembling to the Bavarian trudes or witches, who, in the night would gather the kemels from the grain in the field into their sacks, drink the milk of cows and also of mothers, so that the latters' newborn babies would starve and, finally, in the night ride the men and steal their semen, rendering them impotent. Is it this disorder, which the infantical women expressed in their accounts to other women (farmer's wives and maidservants) about a congestion of the blood or a tumor, "something" dangerous growing hidden inside their bellies? In the infanticide records, it is striking that the label «loose" was employed mainly by male witnesses. This was an old argument used to avoid paying child support to an unmarried mother, which, in the close network of social control, including that over love affairs among village youth, could at worst turn to the disadvantage of another male. The accusation of «looseness », aroused and perpetuated by «talk», bears the stamp of the village moral tribunal, and I will return later to the role of men in this institution. The sentencing of an infanticidal women before the Munich assizes was thus often preceded by slander from the village. For the village, the issue was not that she had a illegitimate child and that she had killed it, but that she was a loose woman, a threat to the village. It wanted rid of her and for this the village used the court in Munich. Before the infanticidal woman could publicly become a criminal without mitigating circumstances (which only the village could provide), the rural community had already deprived the maidservant of any possible honorable existence.

The Upper Bavarian village incendiaries ${ }^{22}$, whom I will now discuss, came from the same social background as the infanticides and the fathers of their children. In one case, in fact, the father of an illegitimate child, who had been killed, set fire to the farm belonging to the father of his beloved, now in prison. She, a farmer's daughter, had been pregnant with the child of a servant.

Arson is the classic crime among those defined by the Reich's Penal Code as constituting a public danger, alongside poisoning wells. The prominent place that 
arson has always held in the public imagination is explained by two factors: although it is usually particular structures which are set on fire, the natural force unleashed can not only easily spread to other buildings, it can injure or kill the people within, especially given the crowded, wooden architecture of old cities. Secondly, the intention to kill people by means of fire has always been regarded as particularly insidious.

The double nature of malicious incendiary murder and the public danger posed by fire are separated in the Reich Penal Code's description of offences, (Paragraphs 306 to 311 ): setting fire to an occupied building is punishable by hard labor $(\$ 306)$ and, in those cases either where a person is killed in the fire or where the incendiary raised the fire for the purpose of murder, robbery, or rebellion, the sentence was set at ten years to life imprisonment $(\$ 307)$; whereas in the other paragraphs the idea of public danger is emphasized. By extinguishing a (non-damaging), fire one raised oneself, a culprit gained immunity from prosecution. Here the law $(\S 308)$ threatened anyone setting fire to unoccupied buildings or objects, including those they owned themselves, where a danger existed that the fire might spread to the property of others, with up to ten years' hard labor. Even where extenuating circumstances obtained, the minimum sentence was six months' imprisonment ${ }^{23}$.

In the 120 arson cases which have survived in the records of the Upper Bavarian courts of assize, not one person was injured or killed, although most cases involved occupied buildings. The issue of «public danger» was also not central, since most of the structures involved were isolated farmsteads. If the two main criteria for the offence of arson, as defined by legal tradition, were not fulfilled, what was at stake in village fires?

Like infanticide, fire-raising was a typically rural crime, one implicating all areas of life and all strata of Upper Bavarian village society. And incendiarism was above all a male crime. Conflicts between farmers and farmhands, arguments over wages, bad feelings over unjust treatment or insult, or inadequate recognition for their work, led farmhands to set fires. Day laborers whose work was being replaced by the new threshing machines, and who had thus become superfluous at harvest time, wrote letters threatening arson or actually set farms ablaze, as in the Inn region in $1895^{24}$. Conflicts between master and servant, between farmers and the landless, were not the only reason for incendiary acts. Fires could also point to family troubles. Disagreements over inheritance between brothers, the refusal of farmers to turn over the property to their eldest sons, conflicts between young and old and the disaster of farms run into the ground by mismanagement could all culminate in fireraising.

In a large portion of the cases, the perpetrators stated their motive as «revenge». For many middle-class judges, this was an archaic concept, which could only appear pathological. Thus incendarism became a central topic for criminal psychiatry, which, in the second half of the nineteenth century, had become an important

23 Liszt (1903, p. 494 ff.). See also Meyer (1888, p. 904 ff.).

24 On serial arson as collective political protest in nineteenth-century England, see esp. Hobsbawm and Rudé (1969). In Bavaria, threats and acts of arson were an individual rather than collective responses on the part of day laborers to the introduction of the steam-powered threshing machine and the ensuing loss of employment. Farmers nevertheless harbored a latent fear that these unemployed laborers might resort to rebellion, which the suggestive language of the threatening letters only exacerbated. See StAM, St Anw 15468 and StAM, LRA 13990. 
adjunct to the bourgeois legal system ${ }^{25}$. Removed from their peasant-village context, and exposed to the psychiatrist's gaze, the individual traces of idiocy, dementia praecox and mental and moral deficiency were now to be isolated ${ }^{26}$. Revenge was transformed into lust for vengence, therefore having the characteristics of mental disease.

Interrogation, and measuring of hands, heads and limbs, which might be disproportionate ${ }^{27}$, extinguished the incendiaries' specific language. The individual arsonist was stripped of his peasant features. He was now either normal, abnormal or an idiot, and as such was categorized along the lines of a bourgeois sense of functioning. The fire-setters filled a file in the archives of psychiatric asylums. In order to understand what fire-raising - an excessive reaction to often seemingly banal conflicts - was really about, I will regard the fire itself as a form of speech.

What were the fire's targets? At the most literal level, they involved wooden barns and sheds, often with a straw roof, filled with hay, straw and grain stocks which frequently represented an entire year's agricultural labor. But the outbuildings did not stand alone, and the compact construction of Bavarian farmsteads, with sheds, barns, stables and farmhouse forming a unit, meant that the fire could flare up quickly in the straw and spread to other buildings, threatening people and animals as well as property. In the 120 cases I studied, there were no injuries or deaths, since the fires were always discovered in time, but entire farms were burned to the ground nonetheless. Fires were very frequent, and incendiaries knew how they spread. Acts of arson were thus often intended to affect the entire farmstead, and the farm symbolized the whole of peasant life: the labor stored as grain stocks, the horses and oxen with which farmhands, day laborers and farmers cultivated the fields, and the cows and calves which constituted the basis of dairy farming. An attack on the dairy cattle was often directed particularly at the farmer's wife and milkmaids, who milked the cows and raised the calves.

The farmhouse, finally, was the place where the whole peasant family - parents, children and servants - came together to eat and gathered after work in the evening, and also where most slept. Membership in peasant village society in Upper Bavaria meant belonging to a peasant household, and even maidservants and farmhands from outside were considered children of the house. The farmhouse and its center, the parlor with its stove, were and symbolized the reservoir of emotional ties among the household's members. To be excluded from the farmer's wife's hearth, from the fellowship of the table and the warmth of the domesticated fire was an emotional blow which, as the records show, was experienced as a withdrawal of love. For a farmhand standing outside, a lighted farmhouse parlor could symbolize the neglect, insults, misunderstandings, dislike and rejection he had experienced. Eighty-five per cent of incendiaries were unmarried, without a hearth of their own and thus, when they lost their jobs, frequently homeless. There was another, deeper dimension to their exclusion from the farm's hearth, however, for it signified their distance

25 See, for example, Mönkemöller (1912); Reiss (1909); Tö́ben (1917); Jessen (1860); Jaspers (1909); Casper (1846). Important for classifications of the «incendiary compulsion » is Kraepelin (1896). For a general account of the development of psychiatry in the nineteenth century see Dömer (1969); Blasius (1980); Jervis (1978).

26 See, for example, the extensive reports by provincial medical examiners and the Munich regional insane asylum in StAM, St Anw 1625, 1635, 1483, 1613.

27 StAM, St Anw 1635. 
from the place of women and the mother, whom the farmer's wife had come to embody.

A farmstead, seen through the eyes of an outsider or a poor cottager from the village, also spoke of something else, of property, of wealth and poverty in the village, of power and status. In its solidity, rich decorations and self-confidence, it could represent the right of the socially powerful, substantiating the feelings of impotence that had gripped those weaker and less propertied.

The attack was not directed at the body, but rather at what the farmer's person represented. As accused incendiaries announced in village taverns, "revenge, revenge has been sworn ", and only an «extraordinary deed ${ }^{28}$ could end the hate and despair which in some cases had been building up for months. It seems as if men and women in this Upper Bavarian village society had different ways of expressing their disasters. Some infanticidal women spoke the language of their bodies, social disorder appears as an incorporated, uncontrolable, dangerous growth inside their bellies, hidden from the eyes of the public. While the men let their conflicts explode into the open of the village public - by setting fire. They wanted everybody to see, to know, and finally to understand when the fire blazed up over the village in the dead of night. Everyone ran to save what they could, but also to interpret the drama which had now reached its climax. The scene of the fire was the place where the villagers finally identified the incendiary, but also the place where they paused for a moment to think about justice and injustice, because the fire implicated not only a perpetrator, but also the accused - the farmer, the hardhearted father, the bad son and his wife who allowed the farm to be made over to them, only to feed their old father on scraps. To this extent, the incendiary's fire was a public declaration, a theatrical staging of farm conflicts, between master and servant, between have's and havenot's, and within families. The object of destruction signified that which normally held together and sustained the feelings and the economy of rural life. That is why the villagers so greatly feared arson, because it cut to the heart of peasant existence, with its respect for property. And it is also why incendiaries were immediately turned over to the constable and the courts. Some, however, turned themselves in. The fire had apparently had a cathartic effect, consuming the hatred they felt and reestablishing their inner equilibrium. And the entire village had been there to witness the settling of the score. Only now, before judges and psychiatrists, could some of the perpetrators speak of their feelings of indignity, rejection and envy. These feelings were bound to seem small and shabby, though, in the face of the damage they had caused, which the court now calculated down to the last penny. The sentences incendiaries faced were very long, but many appear to have reckoned with this even before they turned themselves in; it was the price they had to pay for reestablishing their peasant identity and their honor in the village.

The crimes of arson, defined by the Reich's Penal Code as a danger to the public, were characterized by Franz von Liszt as «the unleashing, for the achievement of ends hostile to society and humanity, of natural forces which otherwise play an outstanding role in the service of humanity and its objectives ... He who unleashes the power of nature cannot determine the limits of its effects, nor foresee the results which his action entails: nature unbound mocks his power and his foresight ${ }^{29}$. 
These sentences from von Liszt seemed to be a signpost, but the path took me backward rather than foreward. In the peasant society which I was analyzing, the approach to nature, its domestication and harnessing, were at the very center of human labor. Everybody knew the power of the fire that lightning or a badly constructed chimney could trigger. And this knowledge and the fear of it were deeply rooted in each member of peasant society. Did this mean that it was precisely the knowledge of fire's incalculable power which made fire-setting a central crime of rural society? Were there cyclical reversions to the wild state, a wilderness in which the nineteenth-century bourgeoisie had placed the peasant, with idealizing intentions ${ }^{30}$ ? One can also ask what was «un-leashed » before it broke out as a fire? The ties of work, household, family, of honor and with it, of the village itself. The fire spoke of the loss of these ties, of their dissolution in hate and revenge. It spoke a language of reversion to a wild state, which also addressed the social and cultural order of the village, and was understood as such.

Who are the hunters of the Upper Bavarian poaching records ? Farmers and their sons, day laborers, farmhands, almost every man in the Upper Bavarian village hunted, or rather poached, because scarcely a one was authorized to do so by an «exclusive right to the pursuit of fair game ${ }^{31}$. They engaged in hunting $\ll$ in places where they were not allowed to do so ". But they also hunted, as the law intended, «where the game was». This was the case when a farmer shot a deer in his fields where it was eating grain, or captured a hare during the harvest because it meant a tasty meal. But the villagers hunted everywhere, since not all of them had fields of their own. They hunted on the preserves of the King, or Count Arco, or a Munich Counsellor of Justice, for game did not recognize the borders of the hunting grounds, neither were these borders inscribed on the villagers' souls. Overstepping boundaries was part of the joy of hunting. But villagers did not follow « wounded animals onto socalled foreign territory » because it violated their hunter's honor to chase game, and would have shown them to be poor sportsmen ${ }^{32}$. Of course the farmers, farmhands and other young men «tracked » game and «crept up» on it, knowing where the animals lived. The forests and mountains were, after all, the realm of their frontier-crossing vagabondage, and they plumbed its secrets and those of the animals. They «also appropriated the animals " - as the legal code puts it -, in a strictly hierarchical fashion: deer for the farmer, hares for the servants, whether the purpose was to feed a hungry family, to lay on a feast or to win the heart of a dairy maid with a leg of vension ${ }^{33}$. After all, the main thing was to demonstrate the hunt's success, their own readiness with a gun and yet another triumph over the despised gamekeepers. The crime of aggravated poaching, as defined in Penal Code $\$ 293$ did not apply to peasant poachers because it violated their ethical code and their love of animals to hunt with snares, nets, traps or other equipment. Commercial poaching, as defined in $\S 294$, which used precisely these methods, was not the business of the village

30 On the construction of the peasant as «noble savage", see Moser (1985, esp. p. 369).

31 Liszt (1903, p. 453ff.). Here and in the following section, I paraphrase the terminology used in the legal code.

32 The villagers' implicit criticism of merciless battues, as in StAM, StAnw 15476, was also directed at aristocratic hunting practices. On this and on the history of hunting, Eckardt (1976).

33 See, for example the cases in StAM, AR 3161/234; St AM AG 34816, 34813; StAM, St Anw 15410; StAM AR 3162/239, 3147/68. 
population, which was often the victim of commercial poachers, who might for example slaughter a pregnant ewe in a meadow at night and sell it as edible meat to the next obscure inn on the village outskirts ${ }^{34}$.

The peasants were in agreement with the law to the extent that they observed the rules of sportsmanship. They did not have to be taught the hunter's code of honor, rooted as it was in peasant society's own natural economy ${ }^{35}$.

For the peasants, it went without saying that the forest, game and the hunt were free. This notion belonged to a genuinely peasant relationship to their natural surroundings, which they sought to dominate and use, but which also dominated them. The relationship between peasants and animals, which expressed itself in the hunt as much as in stockbreeding, was one based upon respect. It possessed a quality of mutuality, and thus a roe-deer, a stag or a chamois had a right to be hunted skillfully, a right to honor. And for that reason this relationship could not rest on property rights.

In the mind of the peasant hunter, it was in the nature of wildlife that it not be fenced in in a preserve, that it was wild. This specific wilderness, populated by animals, surrounded the village, and it represented the Other in the village's peasant culture. It was the place a boy had to traverse to become a man in the village: the place of dangerous freedom, where he went at night to confront the dangerous buck and the gamekeeper, the representative of the authorities - an encounter with a frequently deadly ending. It was also the place of manhood, when he proclaimed the success of the adventure to the village.

For the Bavarian peasants, and the young men among them in particular, poaching was at once a criminal offense and a ritual initiation into manhood. The fact that poaching was a crime had been part of the game for centuries, and this did not change when the old feudal hunting law was replaced by a new one in $1850^{36}$. Young men needed to prove their courage and pluck in order to be accepted in the village, above all by the girls. Nighttime, when youths roamed the wilderness in search of game was also the time of confrontation with their emerging sexuality, which represented both a challenge and their domestication and reintegration into the village.

In fantastical and oft-repeated legends about poachers, which assumed poetic forms, a cultural text took shape. Songs and witnesses' stories about poachers spoke a language which could be identical with the language of village courtship ${ }^{37}$. A police magistrate was confused by the case of a farmer's son who accused a farmhand of having shot a doe at the edge of a forest one moonlit night. After the animal's hairs appeared to have been identified on the poacher's jacket, though, the farmer's son, regretting his accusation, now told the judge that to shoot a doe could also mean to «have» one's beloved $d^{38}$. The farmer's son had - in accusing the servant of shooting a doe - taken revenge. The servant had publicly gossiped about the

34 Such a case is described in StAM, St Anw 15448.

35 On the concept of the peasant «natural economy », see Beck's study (1986).

36 See Endres (1901); Höcht (1893); Die Bayerische Gesetzgebung... (1864); Eckardt (1976, p. 289).

37 Numerous songs about poachers are collected in Pauli (1934), and Schmidkunz (1938). On the culture of courtship in the Alpine region, see Peter (1981). For an analysis of poaching songs as love songs and texts of initiation into manhood and gender relations in the village peasant world, see Schulte (1989, p. 226ff.). On folk-songs as source materials, see esp. Brednich, Röhrich and Suppan (1972); Bausinger (1968, p. 262).

38 St AM, AG 34805. 
farmer's son's forbidden relationship with a servant girl. The verdict could grasp only one reality: that of poaching. For the other there was no language, and no paragraph in the legal code. But maybe this other side of poaching, embodied in this story, can be better understood when we look at the Upper Bavarian and Alpine Poacher songs. These songs, in which the realm of the animals, the wild and the human merge, changing their topics and words at each presentation, and, being danced at festivities by women and men alike, speak the forbidden in this peasant culture: the lust for hunting and at the same time provoking the authorities, the fantasies and desires of undomesticated sexuality, which cross the lines of the hierarchical structure of the village. And these songs are the only way in which a homoerotic discourse among the male youth is allowed. At the same time, being enacted again and again, they show us how peasant culture tranforms its wilderness into a poetic image.

The language of poaching has many layers. It goes from the unambiguous level of the law to the traditions of manhood and gender relations in peasant culture. And the meaning of «poaching " could only be fixed when a denunciation had made matters unmistakeably clear. One villager accused another of poaching only when some other conflict was already smouldering in the background. Even when both parties, and sometimes half the village, had faced each other as witnesses, it was not necessarily clear which story was actually at stake ${ }^{39}$.

Sometimes the village used the court as a place to negotiate its own conflicts, but it did not accept the court's logic, mocking the legal system instead. The same men and boys who faced each other over an accusation of poaching, or because of a brawl, could work together in that very village moral tribunal which the state had been fighting for centuries, a tribunal which appeared in disguises the bourgeois judges knew all too well from descriptions of poachers: sporting blackened faces and straw beards. Known variously as Haberfeldtreiben, rough music or charivari, these village courts of censure or morality - or mummeries, as burghers who had recently discovered folklore called them - remained a considerable institution of village justice all over Europe into the nineteenth century ${ }^{40}$. The actors were unmarried young men from all strata of village society, farmer's sons, farmhands and artisans alike. Here the village presented outsiders with a united front, temporarily putting aside festering social conflicts. This group of marriageable men, as one might call them, had assumed a social function, namely control over one area of the village system of norms and values. In this way the young men were themselves socialized into this very normative structure. The reason for charivaris, and the object of the obscene satirical verses and lampoons recited here with so much noise and racket, was chiefly, sexual misconduct: adultery, incest or sexual relations between unequals, for example between a farmer and a maidservant. This misconduct was publicly announced and denounced, and the perpetrators exposed and humiliated at night before their own houses. A charivari before one's house meant the loss of honor, and there was no appealing the decision of this ritual court. Only by submitting to its verdict could one hope to be be fully reintegrated into the mesh of village

39 See, for example, St AM, St Anw 7114, in which the feud between two peasant clans was brought before the courts in the form of an accusation of poaching.

40 Fundamental newer studies of charivari and the culture of protest in early modern Europe include: Thompson (1972); Davis (1971); Le Goff and Schmitt (1981). The most important recent study on Bavaria is Ettenhuber (1983). 
relationships. This exalted and theatrical show of symbolic power possessed efficacy in the village. And it was precisely this independent rural moral law which attracted the attention of Church and State, particularly from the early nineteenth century on, because it impinged on their monopoly of morality and power. Participants in charivaris were liable to severe penalties. It became clear that the state had understood the villagers quite plainly when the charivari, as an institution of village autonomy, was directed against representatives of Church and State. This was the case in 1891, when a two-hundred-man charivari, planned with almost military precision, set off for the market town of Miesbach, south of Munich, seat of the district council and court, in what the bill of indictment described as a «grand demonstration of rough justice against the secular and clerical authorities' attempts to abolish charivaris ${ }^{41}$. This march was also a carnivalesque enactment of the world turned upside down ${ }^{42}$, where not only peasants but also public authorities were showered with insulting verses about adultery, incest, promiscuous behavior and the violation of priestly celibacy. The targets included a constable, a priest, a higher district judge, a large landowner, a councillor of commerce, a mine director and, last but not least, the archbishop. In this way the protestors confronted the authorities with «their text». As Helga Ettenhuber, in her important recent study of Bavarian charivaris, suggests, it was precisely with this «ritual, forbidden and proscribed by the state, which represented to the rural world a symbol of its own culture, that peasants challenged state authority. In a sense, the noisy spectacle symbolized an assertion of control and authority over their own social living space which the rural commune had in reality long since lost ${ }^{43}$.

This was indeed the case. All that remained was a misunderstanding - and high penalties. The fact that the Miesbach protestors marched off with rifles, and that there was a shoot-out resulting in injuries, shows that this tribunal had abandoned the realm of purely symbolic violence. For the first time, it spoke with the methods that the opposing constabulary mirrored ${ }^{44}$.

Bourgeois law and peasant norms met in the courtroom, and with them two «other» texts and languages, which carried their own fields of meaning. But the trial itself is already part of a process of rendering unequivocal and universal that which was ambiguous and particular. When the old world of the peasants uses the court to solve village conflicts, it has already entered the new world, but the bourgeois world also intervenes in that of the peasants. In the process of determining and finding justice, bourgeois or civil society imparts its own norms to peasant society. The nineteenth-century village is not a closed, autonomous system. The bourgeois judge's interrogation makes peasant village culture, which still expresses itself in gestures, drama and symbol, speak in words. And these words are not taken from the dialects of Upper Bavaria. Through them, it begins, unnoticed, to adopt the interpretations bourgeois culture offers. In the twentieth century courtroom, peasant and bourgeois begin increasingly to speak the same language.

41 Quoted in Ettenhuber (1983, p. 186).

42 On the tradition of the carnival and the world turned upside down see Schindler (1992, p. 121-174).

43. Ettenhuber (1983, p. 207).

44 Schindler's suggestion that the «strong-arm tactics » and « verbal radicalism » of 19th-century charivaris heralded the decline of the village youth group's position as a communal conscience is surely correct, see Schindler (1992, p. 227). 


\section{REFERENCES}

Bausinger, H., Formen der Volkspoesie, Bern, 1968.

Beck, R., Naturale Ökonomie. Unterfinning: Bäuerliche Wirtschaft in einem oberbayerischen Dorf des frühen 18. Jahrhunderts, Munich, 1986.

Blasius, D., Der verwaltete Wahnsinn. Eine Sozialgeschichte des Irrenhauses, Frankfurt a.M., 1980.

Brednich, R.W., Röhrich, L., Suppan, W., (eds.), Das Handbuch des Volksliedes, Vol. 2, Munich, 1972.

Casper, J.L., Denkwürdigkeiten zur medizinischen Statistik und Staatsarzneikunde. Das Gespenst des Brandstiftungstriebes, Berlin, 1846.

Chartier, R., Intellectual History or Sociocultural History? in La Capra, D., Kaplan, S. L., (eds.), Modern European Intellectual History: Reappraisals and New Perspectives, Ithaca, N.Y., 1982.

Davis, N.Z., The reasons of misrule: youth groups and charivaris in Sixteenth-Century France, in Society and Culture in Early Modern France, Stanford, 1971, p. 97-123.

Die Bayerische Gesetzgebung über Jagdausübung, Wildschadenersatz und Jagdfrevel mit den hierzu erlassenen Vollzugsnormen und Polizeivorschriften, new ed published with the permission of the royal ministry of State for the Interior, Munich, 1864.

Dörner, K., Bürger und Irre. Zur Sozialgeschichte und Wissenschaftsoziologie der Psychiatrie, Frankfurt a.M., 1969.

Eckardt, H. W., Herrschaftliche Jagd und bürgerliche Kritik. Zur Geschichte der fürstlichen und adligen Jagdprivilegien vornehmlich im südwestdeutschen Raum, Göttingen, 1976.

Endres, M., Geschichte des Jagdrechtes in Bayern, Forstwirtschaftliches Zentralblatt, 1901, NF 23, p. 170-189.

Ettenhuber, H., Charivari in Bayem. Die Miesbacher Treiben von 1899, in van Dülmen, R., (ed.), Kultur der einfachen Leute, Munich, 1983, p. 180-207.

Hobsbawm, E.J., Rudé, G., Captain Swing, London, 1969.

Höcht, F., Systematische Darstellung des im rechtsrheinischen Bayern geltenden Jagdrechts, Munich, 1893.

Hörger, H., Familienformen einer ländlichen Industriesiedlung im Verlauf des 19. Jahrhunderts, Zeitschrift für bayerische Landesgeschichte, 1978, 41, p. 771-819.

Jaspers, K., Heimweh und Verbrechen, Archiv für Kriminalanthropologie und Kriminalistik, Leipzig, 1909, 35.

Jervis, G., Kritisches Handbuch der Psychiatrie, Frankfurt a.M.,1978.

Jessen, Die Brandstiftungen in Affekten und Geistesstörungen, Kiel, 1860.

Kraepelin, E., Psychiatrie. Ein Lehrbuch für Studierende und Ärzte, Leipzig, 1896.

Le Goff, J., Les mentalités. Une histoire ambiguë, in Faire l'histoire, Paris, 1974, Vol. III, p. 76-94.

Le Goff, J., Schmitt, J.C., (eds.), Le Charivari. Actes de la table ronde... , Paris, 1981.

Lee, W.R., Bastardy and the Socioeconomic Structure of Southern Germany, Journal of Interdisciplinary History, 1977, 7, p. 403-425.

Leoprechting, K. von, Bauernbrauch und Volksglaube in Oberbayern, Munich, 1975 (1855).

Lindner, F., Die unehelichen Geburten als Sozialphänomen. Ein Beitrag zur Statistik der Bevölkerungsbewegung im Königreich Bayem, (Wirtschafts- und Verwaltungsstudien mit besonderer Berücksichtigung Bayerns, 7), Leipzig, 1900.

Liszt, F. von, Lehrbuch des Deutschen Strafrechts, Berlin, 1903 (12th \& 13th eds.). 
Matz, K.J., Pauperismus und Bevölkerung. Die gesetzlichen Ehebeschränkungen in den südddeutschen Staaten während des 19. Jahrhunderts, Industrielle Welt, Stuttgart, 1980, 13.

Meyer, H., Lehrbuch des Deutschen Strafrechts,. Erlangen, 1888 (4th revised ed.).

Mitterauer, M., Familienformen und lllegitimität in ländlichen Gebieten Österreichs, Archiv fuir Sozialgeschichte, 1979, 19, p. 123-188.

Mitterauer, M., Ledige Mütter. Zur Geschichte unehelicher Geburten in Europa, Munich, 1983.

Mönkemöller, O., Zur Psychopathologie des Brandstifters, Archiv für Kriminalanthropologie und Kriminalistik, Leipzig, 1912,48, p.193-310.

Moser, H., Der Folklorismus als Forschungsproblem der Volkskunde Volkskunde im geschichtlichen Wandel. Ergebnisse aus füfzig Jahren volkskundlicher Quellenforschung, Munich \& Berlin, 1985, p. 359-392.

Pauli, K., (ed.), Alte Oberbayerische Volkslieder, Munich, 1934, (6th ed., 1980).

Peter, I., Gasslbrauch und Gasslspruch in Osterreich, Salzburg, 1981.

Rameckers, J.M., Der Kindsmord in der Sturm- und Drang-Periode. Ein Beitrag zur Kulturund Literaturgeschichte des 18. Jahrhunderts, Rotterdam, 1927.

Reiss, Zur Psychopathologie der Brandstifter, Jahresversammlung des Vereins bayerischer Psychiater, Munich, 1909.

Schindler, N., Widerspenstige Leute. Studien zur Volkskultur in der Frïhen Neuzeit, Frankfurt a.M., 1992.

Schmidkunz, W., (ed.), Das Leibhaftige Liederbuch, Wolfenbüttel, 1938.

Schulte, R., Das Dorf im Verhör. Brandstifter, Kindssmörderinnen und Wilderer vor den Schranken des bürgerlichen Gerichts - Oberbayern 1848-1910 Reinbek bei Hamburg, 1989, (in English: The Village in Court. Arson, Infanticide, and Poaching in the Court Records of Upper Bavaria, 1848-1910, Cambridge, 1994).

Schweyer, F., Schäffau. Eine oberbayerische Landgemeinde. Eine wirtschaftliche und soziale Studie, Stuttgart, 1896.

Thompson, E.P., Folklore, anthropology and social history, Indian Historical Review 1977, 3, p. 247-266.

Thompson, E.P., 'Rough music': Le charivari anglais', Annales E.S.C., 1972, 27, p. 285-312.

Többen, H., Beiträge zur Psychologie und Psychopathologie der Brandstifter, Berlin, 1917.

Ulbricht, O., Kindsmord und Aufklärung in Deutschland, Munich, 1990.

Wächtershäuser, W., Das Verbrechen des Kindsmords im Zeitalter der Aufklärung. Eine rechtsgeschichtliche Untersuchung der dogmatischen, personalen und rechtssoziologischen Aspekte (Quellen und Forschungen zur Strafrechtsgeschichte, vol. 3.), Berlin, 1973.

Weber, B., Die Kindsmörderin im deutschen Schrifttum von 1770 bis 1795, Bonn, 1974.

Wittrock, Ch., Abtreibung und Kindsmord in der neueren deutschen Literatur, Frankfurt a.M., 1978. 